\title{
Macroeconomic Factors of Emerging Stock Market: The Evidence from Thailand
}

\author{
Nopphon Tangjitprom \\ Martin de Tours School of Management and Economics \\ Assumption University, Bangkok, Thailand \\ Tel: +66-85-815-6177Ｅ-mail: tnopphon@gmail.com
}

Received: December 5, 2011

Accepted: January 24, 2012 Published: April 15, 2012

doi:10.5430/ijfr.v3n2p105

URL: http://dx.doi.org/10.5430/ijfr.v3n2p105

\begin{abstract}
This paper aims to examine the importance of macroeconomic factors to determine the performance of stock market. The regression analysis is used to examine this relationship. The result shows that macroeconomic variables can explain stock return significantly after adjusting for some lags of data availability. Moreover, the lead-lag relationship is examined by Vector Autoregression model and Granger causality test. They reveal that macroeconomic variables are less important to predict future stock return whereas stock return can be used to predict macroeconomic variables more. In the other word, stock return is good candidate as a leading economic indicator. Finally, the variance decomposition technique reveals that interest rate is the most important macroeconomic variable to explain the variance in stock return. However, it is clearly noticed that all macroeconomic variables can explain only a little variance in stock return.
\end{abstract}

Keywords: Stock, Macroeconomics, Stock Exchange of Thailand, Vector Autoregression

\section{Introduction}

Many studies try to examine the factors affecting the stock return. The most popular factor model is the single factor model named Capital Asset Pricing Model or CAPM that uses the market factor as the sole factor to determine the stock return. Because of its advantages like good theoretical background and convenient to use, this single factor model is very popular in most of finance textbooks and popular to be used by many practitioners. However, many scholars propose the multi-factor model to explain the stock return. One of the most popular multi-factor models is the model using macroeconomic variables to explain stock returns.

In this study, four macroeconomic variables are used. Unemployment rate is used as the proxy of general economic condition and cyclical factor. Interest rate is measured by five year government bond yield. Inflation is estimated from consumer price index. Exchange rate will represent the international sections of economy. The exchange rate between Baht and US Dollar is used in form of Baht/US Dollar.

The regression analysis is used to examine the relationship between stock return and macroeconomic variables. The unit root test and stationary test is conducted to ensure that the data in the model are stationary in order to avoid a spurious result. Thereafter, the lead-lag relationship among variables is examined by Vector Autoregression model and Granger causality test. The result will reveal whether the macroeconomic variable can be useful to predict the future stock return or the stock return can be used to predict future macroeconomic variables. Finally, variance decomposition technique is conducted to examine how stock return is sensitive to each macroeconomic factor. Sectorial indices are also included in this analysis in order to see whether each industry is sensitive to macroeconomic variables differently.

The outline of this paper is as followings; Section 2 provides macroeconomic model in the literatures, Section 3 reports data and methodology used in this paper, Section 4 presents the result of statistical tests, and Section 5 is the conclusion of this study.

\section{Macroeconomic Factors and Stock Return.}

Many studies have been conducted about the factors affecting the stock returns. One of the most popular factor models discussed in many literatures and textbooks are the single factor model, known as Capital Asset Pricing Model or CAPM, which is developed by Sharpe (1964), Lintner (1965), Mossin (1966) and Black (1972). The rational behind this single factor mode is derived from the concept of diversification introduced by Markowitz (1952). Well-diversified investors 
should concern only systematic risk. This systematic risk can be captured by sensitiveness of each stock to a change in overall market, which is measured by Beta. The market factor is the only one factor determining stock return. Because of the good theoretical background and simple representation of the model, the CAPM is very popular as the model used to determine the stock return in most of finance textbooks and used by many practitioners in stock market.

However, the numerous sets of assumptions inconsistent with the real world lead to many criticisms of CAPM. Many scholars propose the multi-factor model instead of single model. Ross (1976) introduces the Arbitrage Pricing Theory or APT, which is later formulated by Roll and Ross (1980). APT model is the multi-factor model and claims that the stock return can be explained by unexpected changes or shocks of possible multiple factors. Chen, Roll, and Ross (1986) perform the empirical study for APT model and identify that surprise or shock in macroeconomic variables can explain the stock return significantly. Those variables are inflation, aggregate outputs determined by industrial production index, default risk premium that can measure confidence of investors, and change in yield curve measured by term premium.

The study about macroeconomic variables and stock return become popular since then. Many scholars use both traditional and new technique in order to verify the importance of macroeconomic factors. Chen, Wang and Cheng (2009) perform the study about stock return and exchange rate. They use quantile regression to study whether exchange rate can influence stock return and whether stock return can influence exchange rate. The result shows that the exchange rate has significantly effect on stock return in most of quantiles. However, the stock return has no effect to exchange rate fluctuation. Gregoriou, Kontonikas, MacDonald and Montagnoli (2009) study the impact of monetary policy on stock return in both aggregrate and sectorial level using the time-series and panel regression models. They use the 3-month sterling LIBOR futures contract to generate the monetary policy shock. The result shows the significant impact on stock return from both expected and unexpected changes in interest rate. Furthermore, they detect the structural break as the relationship between stock return and interest rate becomes positive during the recession period. Kolluri and Wahab (2008) use asymmetric test to examine the relationship between stock return and inflation. During the low inflation environment, the negative relationship between both variables is found. However, this relationship will reverse to be positive during high inflation environment. They conclude this finding as inflation protection characteristic of stock return. Asai and Shiba (1995) study the lead-lagged relationship between stock market and macroeconomic variables by using Vector Autoregression technique. The macroeconomic variables used in the study are industrial production index, interest rate, and wholesales price index. The result reveals that the macroeconomic variables have an effect on the stock market but the stock market cannot explain the future economic performance.

The study about this macroeconomic influence on stock market is an interesting topic not only in major stock markets but also in other markets. For European countries, Czaja and Scholz (2006) examine how German stock returns are sensitive to changes in interest rates. The evidence shows that term structure of interest rates is very critical factor to explain the sensitivity of stock return in Germany in both overall and industry level. Hess (2003) uses Vector Error Correction Model or VECM and variance decomposition to examine the impact of macroeconomic factors to stock market in Switzerland. The result of variance decomposition reveals that each sector is sensitive to different innovations in macroeconomic variables. He points that this information is useful for strategic asset allocation in different sectors in order to control the macroeconomic risks. Hondroyiannis and Papapetrou (2001) study the interaction among macroeconomic variables and stock market in Greece. The result shows that the stock market movement cannot be the leading indicator of macroeconomic fluctuation whereas the macroeconomic can partially explain the fluctuation in stock market. Federova and Pankratov (2010) use EGARCH model to study the influence of macroeconomic variables on Russian market. They find that stock market is relying heavily on the oil price and US Dollar exchange rate. Buyuksalvarci (2010) study the effect of macroeconomic factors on stock return in Istunbul stock market in Turkey. Seven macroeconomic factors including consumer price index, money market interest rate, gold price, industrial production index, oil price, foreign exchange rate and money supply are used in the study. The result shows that money supply has significantly positive effect on stock return whereas the interest rate, production index, oil price, and exchange rate have significantly negative effect. The studies are also popular in emerging Asian countries. Adrangi, Chatrath, and Raffiee (1999) use Fama's proxy hypothesis framework to study the relationship between real stock returns, inflation and real activities. They find the evidences of negative relationship between inflation and real stock return in Korea market. They explain this negative relationship to inflationary pressure to future potential profits of listed companies and higher nominal discount rate. Maysami, Howe, and Hamzah (2004)examine the relationship between stock market and macroeconomic variables in Singapore. The result shows that there is cointegration between all macroeconomic variables in the study and market index. They also examine for sectorial level and find cointegration between property sector and all macroeconomic variables. However, for finance sector, money supply and real economic activities are not significant. For hotel sector, interest rates and money supply are insignificant. Singh, Mehta, and Varsha (2011) use GDP, employment rate, exchange rate, inflation and money supply as macroeconomic variables to 
determine the relationship with stock return in Taiwan. They find out that exchange rate, GDP and inflation are the significant factors whereas employment rate and money supply are insignificant. Pal and Mittal (2011) examine the long-term relationship between stock return and macroeconomic variables in India. They find the co-integration between them. Most variables like interest rate, inflation rate, and exchange rate have the significant impact on stock return. However, the gross domestic saving has no impact on stock return. Mohammad, Hussain, Jalil and Ali (2009) study the macroeconomic factors in Karachi Stock Exchange in Pakistan. The result reveals that industrial production and gross fixed capital formation, which can be considered as internal factors, are insignificant. The significant factors are external factors that can be manipulated by policy makers like foreign exchange reserve, exchange rate, and board money supply.

\section{Data and Methodology}

The macroeconomic variables in Thailand are collected based on monthly basis since January 2001 to December 2010. The stock indices are collected for the same period. Due to unavailability of monthly GDP data in Thailand, the monthly unemployment rate is used to represent the general business condition and business cycle factor as in Brooks and Tsolocos (1999). Five-year government bond yield represents the level of interest rate. Monthly consumer price index represents the inflation factor. For international activities, the nominal exchange rate between Baht and US Dollar is used.

The augmented Dickey-Fuller test of unit root (Dickey and Fuller, 1979) is conducted to ensure the validity of analysis because the non-stationary data can create spurious result. The KPSS test (Kwiatkowski, Phillips, Schmidt, and Shin, 1992) of stationary is also used to confirm with the unit root test result. The data series is stationary if the null hypothesis of ADF test can be rejected but fail to reject for KPSS test. In the other hand, the data series is non-stationary if the null hypothesis of ADF test cannot be rejected but the null hypothesis of KPSS test is rejected. If the data series is non-stationary, the differencing technique will be used to transform the data to be stationary.

Table 1 reports the result of unit root and stationary test. Both ADF and KPSS test confirm that four of five data series are non-stationary, which are STOCK, UMEMPLOY, CPI, and DOLLAR. Based on their characteristic, STOCK, CPI and DOLLAR are transformed to logarithm and the first differencing of them is used. For UNEMPLOY, only fist difference is computed. The result is that four data series are stationary after first differencing, implying that these data series are first-level integration. Only BOND5Y is stationary at level.

The stationary data series can be used to run the regression analysis without the spurious result. The regression model for examining the relationship between macroeconomic variables and stock market is shown below.

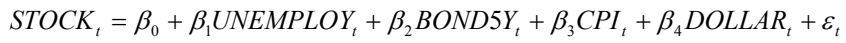

STOCK is the log difference of monthly stock market index. This represents the average monthly stock return for the whole market. UNEMPLOY is the change in monthly unemployment rate. BOND5Y is used to represent the interest rate level, which is from five-year government bond yield. CPI is the log difference of monthly consumer price index, which represents the monthly inflation rate. DOLLAR is the log difference of exchange rate of US Dollar in form of Baht per Dollar. This will represent the monthly percentage change in exchange rate.

In order to examine the lag structure of the above regression model, the Vector Autoregression model (VAR) is used. The information criterion is used to figure the optimal lag length of VAR model. Table 4 reports the information criterion and lag exclusion test used in selection of appropriate lag for VAR model. Akaike Information Criterion (AIC) suggests the optimal lag length is lag 2 but Schwarz Information Criterion (SIC) and Hannan-Quinn Informaiton Criterion (HQIC) suggest lag 1 is the most appropriate one. To confirm this possible result, the lag exclusion test is performed for both lag 1 and lag 2 . The result reveals that, in overall, both lag 1 and lag 2 are significant to be included in VAR model. The VAR (2) model is estimated based on

$Y_{t}=C+A_{1} Y_{t-1}+A_{2} Y_{t-2}+v_{t}$

$\mathrm{Y}_{\mathrm{t}}$ represents the vector of all variables with the dimension of $5 \times 1 . \mathrm{Y}_{\mathrm{t}-1}$ and $\mathrm{Y}_{\mathrm{t}-2}$ is the vectors of the first lag and second lag of all variable with dimension $5 \times 1 . C$ is the vector of constant term. $A_{1}$ and $A_{2}$ is the coefficient matrix for each possible lag with the dimension of $5 \times 5$.

The Granger Causality test (Granger, 1969) is conducted to examine the lead-lag relationship among stock return and all macroeconomic variables. The Granger Causality test can be concluded in four possible results. If the lag of macroeconomic variable can significantly affect stock return but the opposite is not true, it means macroeconomic variable Granger-cause stock return or it is possible that macroeconomic variable can be used to predict the future stock return. However, if the lag of stock return has significant impact on macroeconomic variable but the opposite is not true, it is possible that the stock return is the leading indicator of macroeconomic activities or stock return Granger-cause 
macroeconomic variable. If the lag of macroeconomic variable can significantly affect stock return and vice versa, there are two-way lead-lag relationship between stock return and macroeconomic variable. Otherwise if none is significant, the Granger causality does not exist between two variables.

Finally, the variance decomposition is used to examine the innovation in each macroeconomic factor to the stock market in both overall and sectorial level. All sector indices are used together with the SET50 index, MAI index and the average stock return of top-ten securities. There are 24 sectors with full information available during 2001 to 2010. SET50 index is the index of TOP50 stocks traded in Stock Exchange of Thailand. MAI index is the market index of all stocks in Market for Alternative Investment, which is the Thailand second stock market for small-size and new-established firms. The average stock return for top-ten securities is the equally-weighted average of the ten highest market capitalized stocks traded in Stock Exchange of Thailand.

\section{Analysis and Result}

\subsection{Regression Analysis}

Table 2 reports the result of regression model of equation 1 where the stock return is dependent variable and the macroeconomic variables are explanatory variables. Model 1 is the full model that includes all macroeconomic variables used in this study. The result reveals that only two macroeconomic variables, interest rate and exchange rate, are significant. For interest rate level, it is significantly negative. If the interest rate is higher, all else constant, the stock return will be lower. Higher interest rate can attract the invested fund from stock market to bond market. Furthermore, higher interest rate implies higher discount rate and leads to lower intrinsic value from discounted cash flow valuation. The exchange rate is also significantly negative, which means the stock return will be higher when US Dollar has depreciation against Thai Baht. In the other word, if Thai Baht appreciated, the stock return will be higher. This can be explained by international fund flow as the higher stock return can come from the foreign fund inflow in response to Thai Baht appreciate. The coefficient of unemployment rate is also negative but not significant. The negative relationship means that higher unemployment rate or worse business condition will result in lower performance of stock market. The inflation factor also shows the positive relationship with stock return but it is insignificant.

The regression equation does not suffer from serial correlation and heteroskedasticity. The Durbin-Watson statistic is around 2 and Breusch-Godfrey LM test is insignificant. The White general test for heteroskedasticity is also insignificant. The variance inflation factor is around 1, which implies no multicollinearity problem. To confirm this, the sub-model 1.1 and 1.2 are estimated. Model 1.1 includes only significant explanatory variables and model 1.2 includes only insignificant variables. The result shows that the coefficient of model 1.1 and 1.2 are qualitatively similar to the original model and results of t-test are also similar. Model 1.1 is the model that the insignificance variables are dropped from the original model. However, the adjusted r-square of model 1.1 is slightly lower than the full model implying that dropping insignificant variables cannot lead to a better model.

Both unemployment rate and inflation normally carry the important information about general business condition and cyclical factor. It is surprising that both variables are not significant to explain the stock market performance. It is possible that this comes from the problem of the timing of available data. The data about stock market, interest rate, and exchange rate is available day-to-day. However, the information about interest rate and consumer price index are not available immediately. For example, the data about unemployment rate will be available in the website of Thailand Department of Employment with the lagged period of around two months.

Table 3 reports the result of the regression model which is re-estimated by using two-month lagged of unemployment rate and inflation instead of normal ones as model 2. The result shows clearly that all variables are significant at convention level. Compared to model 1 that is original model, the signs of coefficients are similar.

Tangjitprom (2011) shows that the stock performance in Thailand is abnormally high in December. Therefore, the dummy variable representing December is added in regression equation as shown in model 3 of table 3 . The result is similar that all variables are significant with the similar sign except the dummy for December. Therefore, controlling for possible December effect does not alter the result reported earlier.

The interest rate level is measured by five-year government bond yield, which is long-term interest. The short-term interest as one-month Treasury bill rate is used in stead and report as model 4 in table 3 . Furthermore, the real variables adjusting by inflation rate is used instead of nominal ones as in model 5 Model 6 uses real exchange rate instead of nominal one. The results of model 4 to model 6 reveal the similar one as model 2 . Therefore, using short-term interest instead of long-term interest or using real variables instead of nominal ones does not alter the earlier result. 


\subsection{Lead-Lag Relationship}

Table 5 reports the result of Vector Autoregression or VAR (2) model. There are five equations in the VAR model used in this study. Looking from the equation with STOCK as dependent variable, Only few of lagged macroeconomic variables can explain the stock return. However, lagged variables of stock return can significantly explain most of macroeconomics variables, except unemployment rate. To confirm this finding, Granger causality test is conducted to examine the lead-lag relationship among variables. The result of Granger causality test is reported in table 6 .

Table 6 reveals that unemployment rate slightly Granger-causes the stock return but the opposite is not true. It means that the change in unemployment can be used to predict the future stock return but the stock return cannot help to predict the future unemployment change. For interest rate measured by five-year government bond yield, it Granger-causes the stock return and stock return also Granger-cause the interest rate. For inflation rate and exchange rate, both do not Granger-cause stocks return but stock return Granger-causes both inflation and exchange rate. Therefore, stock return Granger-causes most of macroeconomic variables, except unemployment rate. This implies that the performance of stock market is the good indicator to explain the future macroeconomic situation. This result is consistent with the report generated by Bank of Thailand, which stock market index is used as the leading economic indicator.

\subsection{Variance Decomposition}

Table 7 reports the result of variance decomposition after twelve months for stock return. The result of variance decomposition of stock return is not surprising as the stock return can explain most of variance in itself. Beside the stock return, the interest rate is the variance that can explain more variance in stock return than other macroeconomic variables. The result of variance decomposition yield qualitatively similar even when SET50 index or MAI index is used instead of SET index.

When the return of stock portfolio of top ten firms by market capitalization in used as the stock return, the interest rate can still explain most of variance in stock return. However, it can be noticed that the unemployment rate that is the proxy for general economic condition become less important to explain the variance of stock return. This can roughly imply that the returns in top ten stocks are less cyclical.

For Sectorial index, it is clear that each industry is sensitive to macroeconomic variables differently. Most of them still show the similar result that interest rate can explain most of variance in stock return. However, the importance of interest rate is very high for some industries like Automobile, Petrochemical, Household Products and Transportation. It is possible that these industries require high capital investment and cost of capital investment or interest rate is very important to determine the performance of these industries. Some industries like Personal Care are sensitive more to unemployment rate, which is the proxy for general economic condition or cyclical factor. Meanwhile some industries are less sensitive to any macroeconomic variables. However, only little variance of stock return in Paper industry can be explained by macroeconomic variables.

\section{Conclusion}

The macroeconomic model is examined to see whether macroeconomic factors can explain the performance of stock market. The macroeconomic variables used in this study include unemployment rate, interest rate, inflation rate, and exchange rate. The result of regression analysis reveals that macroeconomic variables can explain stock return significantly in overall. However, unemployment rate and inflation rate are insignificant to determine the stock return. This is possible from the fact that there are some lags before data becomes available. The data about stock return, interest rate or exchange rate can be known in daily basis but inflation rate or unemployment rate need to be waited until the responsible agency will report the calculated number. For example, Department of Employment will report the unemployment rate around 2 month after. Therefore, two-month lag of unemployment rate and inflation rate are used instead of original ones. The result of the new regression model is significant for all macroeconomic variables. Even the short-term interest rate is used instead of long-term interest rate or the real interest rate and real exchange rate are used instead of nominal ones, the results are still similar.

The lead-lag relationships among variables are examined by Granger causality test. The result reveals that only few macroeconomic variables can predict the future stock return whereas the stock return can predict most of future macroeconomic variables, except unemployment rate. This implies that the performance of stock market is the good leading indicator for future macroeconomic condition.

The variance decomposition technique reveals the importance of interest rate to explain the variance in stock return. The result is still similar even MAI index or SET50 index is used instead of SET index. Furthermore, the result reveals that the returns of top-ten stocks are less cyclical. In sectorial level, each industry is sensitive to each macroeconomic variable differently based on the nature of business. However, most of industries are still sensitive more to interest rate. 
The industry like Personal Care is sensitive most to unemployment rate, which implies that it is cyclical industry. Meanwhile the industry like Paper industry is very little sensitive to any of macroeconomic variables.

The result of this study reveals the significance of macroeconomic factors to determine the performance of stock market. However if anyone would like to use the macroeconomic variables to predict the future performance of stock return, it needs to be careful because the macroeconomic variables can explain only little variance in stock return. Moreover, the result of lead-lag relationship shows that macroeconomic variables are less important to predict the future performance of stock return. The result is reverted as stock return tends to be more useful to predict the future macroeconomic condition. The result implies the performance of stock market is the good leading indicator of economy. This implication is consistent with the report generated by Bank of Thailand that they use SET index as one of leading economic indicators.

\section{References}

Adrangi, B., Chatrath, A., \& Raffiee, K. (1999). Inflation, Output, and Stock Prices: Evidence from Two Major Emerging Markets. Inflation, Output, and Stock Prices: Evidence from Two Major Emerging Markets, 23(3), 266-278.

Asai, M., \& Shiba, T. (1995). The Japanese Stock Market and The Macroeconomy: An Empirical Investigation. Financial Engineering and the Japanese Markets, 2, 259-267. http://dx.doi.org/10.1007/BF02425199

Black, F. (1972). Capital Market Equilibrium with Restricted Borrowing. Journal of Business, 45, 444-455. http://dx.doi.org/10.1086/295472

Brooks, C., \& Tsolacos, S. (1999). The impact of economic and financial factors on UK property performance. Journal of Property Research, 16(2), 139-152. http://dx.doi.org/10.1080/095999199368193

Buyuksalvarci, A. (2010). The Effects of Macroeconomics Variables on Stock Returns: Evidence from Turkey. European Journal of Social Sciences, 14(3), 404-416.

Chen, J.-b., Wang, D.-1., \& Cheng, T.-t. (2009). Empirical Study of Relations between Stock Returns and Exchange Rate Fluctuations in China. In S. Wang, Y. Peng, J. Li \& Y. Zeng (Eds.), Cutting-Edge Research Topics on Multiple Criteria Decision Making (Vol. 35, pp. 447-454): Springer Berlin Heidelberg. http://dx.doi.org/10.1007/978-3-642-02298-2_66

Chen, N.-F., Roll, R., \& Ross, S. (1986). Economic Forces and Stock Market. Journal of Business, 59(3), 383-403. http://dx.doi.org/10.1086/296344

Czaja, M.-G., \& Scholz, H. (2006). Sensitivity of Stock Returns to Changes in the Term Structure of Interest Rates Evidence from the German Market. In K.-H. Waldmann \& U. M. Stocker (Eds.), Operations Research Proceedings 2006 (pp. 305-310): Springer Berlin Heidelberg.

Dickey, D. A., \& Fuller, W. A. (1979). Distribution of the Estimators for Autoregressive Time Series With a Unit Root. Journal of the American Statistical Association, 74(366), 427-431. http://dx.doi.org/10.2307/2286348

Fedorova, E. A., \& Pankratov, K. A. (2010). Influence of Macroeconomic Factors on the Russian Stock Market. Studies on Russian Economic Development, 21(2), 165-168. http://dx.doi.org/10.1134/S1075700710020061

Granger, C. (1969). Investigating causal relations by econometric models and cross-spectral methods. Econometrica, 37(3), 424-438. http://dx.doi.org/10.2307/1912791

Gregoriou, A., Kontonikas, A., MacDonald, R., \& Montagnoli, A. (2009). Monetary Policy Shocks and Stock Returns: Evidence from the British market. Financial Markets and Portfolio Management, 23(4), 401-410. http://dx.doi.org/10.1007/s11408-009-0113-2

Hess, M. K. (2003). Sector Specific Impacts of Macroeconomic Fundamentals on the Swiss Stock Market. Financial Market and Portfolio Management, 17(2), 234-245. http://dx.doi.org/10.1007/s11408-003-0205-3

Hondroyiannis, G., \& Papapetrou, E. (2001). Macroeconomic Influences on the Stock Market. Journal of Economics and Finance, 25(1), 33-49. http://dx.doi.org/10.1007/BF02759685

Kolluri, B., \& Wahab, M. (2008). Stock returns and expected inflation: evidence from an asymmetric test specification. Review of Quantitative Finance and Accounting, 30, 371-395. http://dx.doi.org/10.1007/s11156-007-0060-9

Kwiatkowski, D., Phillips, P., Schmidt, P., \& Shin, Y. (1992). Testing the Null Hypothesis of Stationarity against the Alternative of a Unit Root: How Sure Are We That Economic Time Series Have A Unit Root? Journal of Econometrics, 54, 159-178. http://dx.doi.org/10.1016/0304-4076(92)90104-Y 
Lintner, J. (1965). The Valuation of Risk Assets and the Selection of Risky Investments in Stock Portfolios and Capital Budgets. Review of Economics and Statistics, 47, 13-37. http://dx.doi.org/10.2307/1924119

Markowitz, H. (1952). Portfolio Selection. Journal of Finance, 7(1), 77-91. http://dx.doi.org/10.2307/2975974

Maysami, R. C., Howe, L. C., \& Hamzah, M. A. (2004). Relationship between Macroeconomics Variables and Stock Market Indices: Cointegration Evidience from Stock Exchange of Singapore's All-S Sector Indices. Jurnal Pengurusan, 24, 47-77.

Mohammad, S. D., Hussain, A., jalil, M. A., \& Ali, A. (2009). Impact of Macroeconomics Variables on Stock Prices: Emperical Evidance in Case of Kse (Karachi Stock Exchange). European Journal of Scientific Research, 38(1), 96-103.

Mossin, J. (1966). Equilibrium in a Capital Asset Market. Econometrica, 34(4), $768-783$. http://dx.doi.org/10.2307/1910098

Pal, K., \& Mittal, R. (2011). Impact of macroeconomic indicators on Indian capital marketsial markets in the Czech Republic, Hungary, and Poland. Journal of Risk Finance, 12(2), 84-97. http://dx.doi.org/10.2307/2327087

Roll, R., \& Ross, S. (1980). An empirical investigation of the arbitrage pricing theory. Journal of Finance, 35(5), 1073-1103. http://dx.doi.org/10.2307/2327087

Ross, S. (1976). The arbitrage theory of capital asset pricing. Journal of Economic Theory, 13(3), 1073. http://dx.doi.org/10.2307/2977928

Sharpe, W. F. (1964). Capital Asset Prices: A Theory of Market Equilibrium under Donditions of Risk. Journal of Finance, 19, 425-442. http://dx.doi.org/10.2307/2977928

Singh, T., Mehta, S., \& Varsha, M. S. (2011). Macroeconomic factors and stock returns: Evidence from Taiwan. Journal of Economics and International Finance 2(4), 217-227.

Tangjitprom, N. (2011). The Calendar Anomalies of Stock Return in Thailand. Journal of Modern Accounting and Auditing, 7(6).

Table 1. The Result of ADF and KPSS Test for Data

\begin{tabular}{|c|c|c|c|r|}
\hline & \multicolumn{2}{|c|}{ At Level } & \multicolumn{2}{c|}{ First Difference } \\
\hline & ADF & KPSS & ADF & KPSS \\
\hline STOCK & -1.7481 & $0.8166^{* *}$ & $-9.5961^{* *}$ & 0.0667 \\
\hline UNEMPLOY & -2.0374 & $1.2604^{* *}$ & $-4.1563^{* *}$ & 0.1555 \\
\hline BOND5Y & $-2.8111^{*}$ & 0.1579 & & \\
\hline CPI & -0.2471 & $1.2837^{* *}$ & $-7.5429^{* *}$ & 0.0645 \\
\hline DOLLAR & -0.5144 & $1.1815^{* *}$ & $-7.9790^{* *}$ & 0.0839 \\
\hline
\end{tabular}

* indicates significance at $10 \% \quad * *$ indicates significance at $5 \%$ 
Table 2. Regression Result of Stock Return and Macroeconomic Variables.

\begin{tabular}{|c|c|c|c|c|}
\hline & \multicolumn{2}{|c|}{ Model 1} & Model 1.1 & Model 1.2 \\
\hline & $\begin{array}{c}\text { Coefficient } \\
(t \text {-stat })\end{array}$ & VIF & $\begin{array}{c}\text { Coefficient } \\
(t \text {-stat })\end{array}$ & $\begin{array}{c}\text { Coefficient } \\
(t \text {-stat })\end{array}$ \\
\hline Constant & $\begin{array}{c}7.9891 * * \\
(3.362)\end{array}$ & & $\begin{array}{c}8.2460 * * \\
(3.480)\end{array}$ & $\begin{array}{r}0.7779 \\
(1.102)\end{array}$ \\
\hline UNEMPLOY & $\begin{array}{l}-1.2898 \\
(-1.333)\end{array}$ & 1.0180 & & $\begin{array}{l}-1.0272 \\
(-0.981)\end{array}$ \\
\hline BOND5Y & $\begin{array}{c}-2.0821 * * \\
(-3.381)\end{array}$ & 1.0019 & $\begin{array}{c}-2.0659 * * \\
(-3.346)\end{array}$ & \\
\hline CPI & $\begin{array}{c}1.0933 \\
(1.063) \\
\end{array}$ & 1.0352 & & $\begin{array}{l}0.5970 \\
(0.541)\end{array}$ \\
\hline DOLLAR & $\begin{array}{c}-1.2998 * * \\
(-3.447) \\
\end{array}$ & 1.0248 & $\begin{array}{c}-1.2219 * * \\
(-3.269)\end{array}$ & \\
\hline Adjusted R Square & 0.1435 & & 0.1391 & -0.0072 \\
\hline DW & 2.0398 & & 2.0189 & 1.7565 \\
\hline $\mathrm{BG}(3)$ & 2.3110 & & & \\
\hline White & 11.7386 & & & \\
\hline
\end{tabular}

$*$ indicates significance at $10 \% \quad * *$ indicates significance at $5 \%$

Table 3. Regression Result of Stock Return and Macroeconomic Variables with Robustness

(The number in parenthesis is $t$-stat)

\begin{tabular}{|c|c|c|c|c|c|}
\hline & Model 2 & Model 3 & Model 4 & Model 5 & Model 6 \\
\hline Constant & $\begin{array}{c}9.3891 * * \\
(4.049)\end{array}$ & $\begin{array}{c}9.1900 * * \\
(3.974)\end{array}$ & $\begin{array}{c}4.1830^{* *} \\
(3.114)\end{array}$ & $\begin{array}{c}3.2724 * * \\
(2.832)\end{array}$ & $\begin{array}{c}9.0369 * * \\
(3.885)\end{array}$ \\
\hline UNEMPLOY (-2) & $\begin{array}{c}-2.0313 * * \\
(-2.160)\end{array}$ & $\begin{array}{c}-2.2039 * * \\
(-2.335)\end{array}$ & $\begin{array}{c}-1.8062 * \\
(-1.881)\end{array}$ & $\begin{array}{c}-1.7170 * \\
(-1.780)\end{array}$ & $\begin{array}{c}-1.9406^{* *} \\
(-2.062)\end{array}$ \\
\hline BOND5Y & $\begin{array}{c}-2.5254 * * \\
(-4.102)\end{array}$ & $\begin{array}{c}-2.5452 * * \\
(-4.152)\end{array}$ & & & $\begin{array}{c}-2.4828 * * \\
(-4.028)\end{array}$ \\
\hline CPI (-2) & $\begin{array}{r}2.6180 * * \\
(2.566) \\
\end{array}$ & $\begin{array}{r}2.7277 * * \\
(2.678) \\
\end{array}$ & $\begin{array}{r}2.0464 * * \\
(2.002) \\
\end{array}$ & $\begin{array}{r}1.7457^{*} \\
(1.711) \\
\end{array}$ & $\begin{array}{r}2.3677 * * \\
(2.329) \\
\end{array}$ \\
\hline DOLLAR & $\begin{array}{c}-1.3053 * * \\
(-3.518) \\
\end{array}$ & $\begin{array}{c}-1.2425 * * \\
(-3.431) \\
\end{array}$ & $\begin{array}{c}-1.3530 * * \\
(-3.541) \\
\end{array}$ & $\begin{array}{c}-1.4056^{* *} \\
(-3.641) \\
\end{array}$ & \\
\hline DECEMBER & & $\begin{array}{l}3.0701 \\
(1.423) \\
\end{array}$ & & & \\
\hline BILL1M & & & $\begin{array}{c}-1.7819 * * \\
(-3.407) \\
\end{array}$ & & \\
\hline REALINT & & & & $\begin{array}{c}-1.5060 * * \\
(-3.252) \\
\end{array}$ & \\
\hline REALEX & & & & & $\begin{array}{c}-1.2493 * * \\
(-3.430) \\
\end{array}$ \\
\hline Adjusted R Square & 0.1906 & 0.1979 & 0.1584 & 0.1513 & 0.1435 \\
\hline
\end{tabular}

$*$ indicates significance at $10 \% \quad * *$ indicates significance at $5 \%$ 
Table 4. Lag Length Structure of Vector Autoregression Model

\begin{tabular}{|c|c|c|c|}
\hline \multicolumn{4}{|c|}{ Information Criteria } \\
\hline Lag & $\mathrm{AIC}$ & $\mathrm{SIC}$ & HQIC \\
\hline 0 & 16.9740 & 17.0946 & 17.0229 \\
\hline 1 & 14.2663 & 14.9904 & 14.5602 \\
\hline 2 & 14.0991 & 15.4266 & 14.6378 \\
\hline 3 & 14.2319 & 16.1627 & 15.0154 \\
\hline 4 & 14.2873 & 16.8216 & 15.3157 \\
\hline 5 & 14.4577 & 17.5954 & 15.7310 \\
\hline 6 & 14.6421 & 18.3832 & 16.1602 \\
\hline \multicolumn{4}{|c|}{ Lag Exclusion Test (Chi-square) } \\
\hline \multicolumn{2}{|c|}{ Variable } & Lag 1 & $\operatorname{Lag} 2$ \\
\hline \multicolumn{2}{|c|}{ STOCK } & 6.252706 & 8.517239 \\
\hline \multicolumn{2}{|c|}{ UMEMPLOY } & $35.04711 * *$ & $21.94662 * *$ \\
\hline \multicolumn{2}{|c|}{ BOND5Y } & $205.1761 * *$ & $28.64452 * *$ \\
\hline \multicolumn{2}{|c|}{ CPI } & $17.30342 * *$ & $11.64278 * *$ \\
\hline \multicolumn{2}{|c|}{ DOLLAR } & $22.44925 * *$ & 2.245466 \\
\hline \multicolumn{2}{|c|}{ OVERALL } & $295.1197 * *$ & $74.70298 * *$ \\
\hline
\end{tabular}

$*$ indicates significance at $10 \% \quad * *$ indicates significance at $5 \%$

Table 5. Result of Vector Autoregression Model

(The number in parenthesis is t-stat)

\begin{tabular}{|c|c|c|c|c|c|}
\hline & STOCK & UNEMPLOY & BOND5Y & CPI & DOLLAR \\
\hline Constant & $\begin{array}{l}8.2436^{* *} \\
(3.023)\end{array}$ & $\begin{array}{l}-0.0719 \\
(-0.322)\end{array}$ & $\begin{array}{l}0.0904 \\
(0.798)\end{array}$ & $\begin{array}{l}0.1139 \\
(0.507)\end{array}$ & $\begin{array}{l}0.7206 \\
(1.181)\end{array}$ \\
\hline STOCK (-1) & $\begin{array}{l}0.1063 \\
(1.079) \\
\end{array}$ & $\begin{array}{l}-0.0015 \\
(-0.193)\end{array}$ & $\begin{array}{l}0.0085 * * \\
(2.074)\end{array}$ & $\begin{array}{l}0.0174 * * \\
(2.139)\end{array}$ & $\begin{array}{l}-0.0750 * * \\
(-3.406)\end{array}$ \\
\hline STOCK (-2) & $\begin{array}{l}-0.0072 \\
(-0.068) \\
\end{array}$ & $\begin{array}{l}-0.0060 \\
(-0.701) \\
\end{array}$ & $\begin{array}{l}0.0132 * * \\
(3.022)\end{array}$ & $\begin{array}{l}0.0175 * * \\
(2.025) \\
\end{array}$ & $\begin{array}{l}-0.0200 \\
(-0.851) \\
\end{array}$ \\
\hline UNEMPLOY (-1) & $\begin{array}{l}1.3896 \\
(1.222) \\
\end{array}$ & $\begin{array}{l}-0.5314 * * \\
(-5.711) \\
\end{array}$ & $\begin{array}{l}0.0358 \\
(0.759) \\
\end{array}$ & $\begin{array}{l}-0.0508 \\
(-0.542) \\
\end{array}$ & $\begin{array}{l}0.0072 \\
(0.028) \\
\end{array}$ \\
\hline UNEMPLOY (-2) & $\begin{array}{l}-1.6791 \\
(-1.553)\end{array}$ & $\begin{array}{l}-0.3599 * * \\
(-4.067)\end{array}$ & $\begin{array}{l}0.0004 \\
(0.009)\end{array}$ & $\begin{array}{l}-0.0962 \\
(-1.078)\end{array}$ & $\begin{array}{l}-0.0265 \\
(-0.109)\end{array}$ \\
\hline BOND5Y $(-1)$ & $\begin{array}{l}-3.2163 \\
(-1.500)\end{array}$ & $\begin{array}{l}-0.2112 \\
(-1.204)\end{array}$ & $\begin{array}{l}1.1856^{* *} \\
(13.307)\end{array}$ & $\begin{array}{l}-0.1308 \\
(-0.740)\end{array}$ & $\begin{array}{l}0.0066 \\
(0.014)\end{array}$ \\
\hline BOND5Y $(-2)$ & $\begin{array}{l}1.1203 \\
(0.514) \\
\end{array}$ & $\begin{array}{l}0.21887 \\
(1.228)\end{array}$ & $\begin{array}{l}-0.2213 * * \\
(-2.445)\end{array}$ & $\begin{array}{l}0.1268 \\
(0.706)\end{array}$ & $\begin{array}{l}-0.2816 \\
(-0.578)\end{array}$ \\
\hline CPI (-1) & $\begin{array}{l}-0.5644 \\
(-0.473) \\
\end{array}$ & $\begin{array}{l}0.0203 \\
(0.208)\end{array}$ & $\begin{array}{l}0.0786 \\
(1.586) \\
\end{array}$ & $\begin{array}{l}0.2860 * * \\
(2.906)\end{array}$ & $\begin{array}{l}0.2182 \\
(0.818) \\
\end{array}$ \\
\hline CPI (-2) & $\begin{array}{l}2.4497 * * \\
(2.077)\end{array}$ & $\begin{array}{l}-0.1460 \\
(-1.512)\end{array}$ & $\begin{array}{l}0.0904^{*} \\
(1.844)\end{array}$ & $\begin{array}{l}0.0855 \\
(0.880)\end{array}$ & $\begin{array}{l}0.2040 \\
(0.773)\end{array}$ \\
\hline DOLLAR (-1) & $\begin{array}{l}0.4664 \\
(1.017) \\
\end{array}$ & $\begin{array}{l}-0.0359 \\
(-0.958)\end{array}$ & $0.0242 \quad(1.268)$ & $\begin{array}{l}0.0715^{*} \\
(1.892)\end{array}$ & $\begin{array}{l}0.1777^{*} \\
(1.732)\end{array}$ \\
\hline DOLLAR (-2) & $\begin{array}{l}-0.7536^{*} \\
(-1.809)\end{array}$ & $\begin{array}{l}-0.0263 \\
(-0.772)\end{array}$ & $\begin{array}{l}0.0275 \\
(1.590)\end{array}$ & $\begin{array}{l}-0.0659 * \\
(-1.920)\end{array}$ & $\begin{array}{l}-0.0921 \\
(-0.988)\end{array}$ \\
\hline
\end{tabular}

$*$ indicates significance at $10 \% \quad * *$ indicates significance at $5 \%$ 
Table 6. Result Granger Causality Test (Block Exogeneity Test)

\begin{tabular}{|c|c|r|}
\hline Variable & MACRO $\rightarrow$ STOCK & STOCK $\rightarrow$ MACRO \\
\hline UMEMPLOY & $5.9303^{*}$ & 0.5161 \\
\hline BOND5Y & $10.1423^{* *}$ & $12.8080^{* *}$ \\
\hline CPI & 4.3227 & $8.2443^{* *}$ \\
\hline DOLLAR & 3.7285 & $12.0570^{* *}$ \\
\hline
\end{tabular}

* indicates significance at $10 \% \quad * *$ indicates significance at $5 \%$

Table 7. Variance Decomposition after 12 Months for Sectorial Stock Return

\begin{tabular}{|l|c|c|c|c|c|}
\hline & STOCK & UNEMPLOY & BOND5Y & CIP & DOLLAR \\
\hline SET Index & 83.5717 & 2.8816 & $\mathbf{6 . 7 1 0 6}$ & 3.3500 & 3.4861 \\
\hline SET50 Index & 85.4326 & 2.5060 & $\mathbf{5 . 9 4 8 3}$ & 2.7494 & 3.3637 \\
\hline Top 10 & 84.6700 & 0.4598 & $\mathbf{7 . 7 5 7 5}$ & 3.1640 & 3.9488 \\
\hline MAI Index & 82.7901 & 4.4453 & $\mathbf{5 . 7 5 7 3}$ & 2.4114 & 4.5958 \\
\hline Agribusiness & 88.7171 & 3.2665 & $\mathbf{3 . 8 8 1 9}$ & 2.9112 & 1.2233 \\
\hline Automotive & 83.6931 & 1.6295 & $\mathbf{1 0 . 9 6 8 0}$ & 2.6509 & 1.0584 \\
\hline Banking & 87.4477 & $\mathbf{3 . 9 0 9 3}$ & 3.5722 & 1.5857 & 3.4852 \\
\hline Commerce & 90.8116 & 0.6989 & 2.6779 & 1.7106 & $\mathbf{4 . 1 0 1 0}$ \\
\hline Cons Material & 87.0344 & 1.1452 & $\mathbf{6 . 6 5 9 9}$ & 2.1118 & 3.0487 \\
\hline Electron Comp & 87.4210 & 0.9660 & $\mathbf{4 . 6 5 3 5}$ & 3.0569 & 3.9027 \\
\hline Energy\&Utilities & 88.1872 & 1.2700 & $\mathbf{5 . 8 2 7 1}$ & 2.7624 & 1.9533 \\
\hline Fashion & 92.3862 & 1.3385 & $\mathbf{3 . 5 2 6 8}$ & 2.4587 & 0.2899 \\
\hline Finance & 81.1557 & 6.0360 & $\mathbf{6 . 3 3 0 0}$ & 2.5967 & 3.8816 \\
\hline Food\&Beverages & 88.1204 & 0.8068 & $\mathbf{6 . 8 0 0 7}$ & 2.0277 & 2.2444 \\
\hline Health Care & 86.6268 & 0.1197 & 3.4732 & $\mathbf{6 . 6 9 9 4}$ & 3.0809 \\
\hline Home\&Office & 80.5029 & 5.3505 & $\mathbf{8 . 4 8 3 3}$ & 3.5344 & 2.1289 \\
\hline ICT & 83.9830 & 4.6792 & $\mathbf{6 . 2 6 7 4}$ & 2.8493 & 2.2211 \\
\hline Insurance & 84.0693 & 4.1064 & $\mathbf{5 . 6 7 8 7}$ & 4.3424 & 1.8033 \\
\hline Media & 91.9612 & 0.1989 & 2.1115 & $\mathbf{4 . 1 7 0 1}$ & 1.5583 \\
\hline Mining & 92.7830 & 0.0524 & 0.5648 & $\mathbf{5 . 7 1 0 1}$ & 0.8897 \\
\hline Packaging & 88.7670 & 1.5158 & $\mathbf{6 . 7 8 4 9}$ & 2.6735 & 0.2588 \\
\hline Paper & 96.4541 & $\mathbf{2 . 4 4 8 7}$ & 0.5281 & 0.3622 & 0.2069 \\
\hline Personal\&Phama & 87.4847 & $\mathbf{6 . 3 6 5 9}$ & 2.9946 & 2.3028 & 0.8520 \\
\hline Petro\&Chemicals & 82.8399 & 0.4014 & $\mathbf{8 . 3 4 0 2}$ & 4.1236 & 4.2948 \\
\hline Professional & 87.1484 & 0.7246 & 2.8207 & $\mathbf{5 . 1 9 8 4}$ & 4.1079 \\
\hline Property & 89.3615 & 1.9280 & $\mathbf{4 . 0 6 9 1}$ & 1.3804 & 3.2610 \\
\hline Tourism & 91.2515 & 1.4126 & $\mathbf{3 . 0 0 5 8}$ & 2.3473 & 1.9829 \\
\hline Transportation & 81.3937 & 1.2017 & $\mathbf{9 . 1 0 3 6}$ & 4.9959 & 3.3051 \\
\hline
\end{tabular}

Note: The bold number indicates the highest value of variance except from stock return itself. 